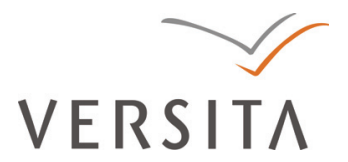

Folia Oeconomica Stetinensia

DOI: $10.2478 / \mathrm{v} 10031-011-0011-4$

\title{
usWNIEIZ
}

Wydzial Nauk Ekonomicznych i Zarządzania Uniwersytetu Szczecińskiego

\section{THE EFFECTS OF DELAYS IN THE DISSEMINATION \\ AND USAGE OF BROADBAND INTERNET}

\author{
Marcin Gryczka, Ph.D. \\ Faculty of Economics and Management \\ University of Szczecin \\ Mickiewicza 64, 71-101 Szczecin \\ e-mail: gryczka@wneiz.pl
}

Received 30 June 2011, Accepted 3 August 2011

\begin{abstract}
Information and telecommunication technology development is undeniably one of the most important factors for global knowledge diffusion and digital society creation processes in the contemporary world economy. The purpose of this paper is to analyze ICT infrastructure advances having taken place in the European Union, Japan and the United States in last fifteen years, and - based on the analysis results - to specify the most significant, present and potential future problems for Polish economy due to its ICT usage backwardness. While ICT infrastructure development level in Poland is closing to the EU averages, still the vital issue is lack of Internet usage possibilities and increasing digital divide between urban and rural regions, which in the near future can constrain a socioeconomic growth and competitiveness of Polish economy.
\end{abstract}

Keywords: information and telecommunication technology, technological change, growth prospects, knowledge diffusion.

JEL classification: O33. 


\section{Introduction}

Intensification of the phenomena associated with the domination of the service sector in global economy, observed in recent decades, results from both the growing importance of socalled intellectual services ${ }^{1}$, as well as from the dynamic progress of the information technology and telecommunication sector. Ensuring an universal access to information is important, however, not only from the standpoint of competitiveness of internationally active entities, but also fundamental for further economic, social and civilizational development of particular countries $^{2}$. Moreover, recent experience shows that apart from modern telecommunication infrastructure providing fast access to the global network ${ }^{3}$, it is also necessary to disseminate knowledge on how its resources can be used for the professional and personal development.

The purpose of this article is first to present the changes in universal access to telecommunication services that have occurred in EU countries, the USA and Japan in the last 15 years, then analyze the situation of Poland in the context of these changes, as well as to point out any possible consequences of negligence in this area for our economy. Selected methods of descriptive statistics have been primarily used for the purposes of analysis, and the main considerations are centred around selected indicators of development of the ICT market in the years 1995-2009.

\section{Development and utilization of broadband infrastructure in Poland relative to other European Union countries}

While at the end of the last century, the development of the ICT market could be described by means of the improving infrastructure-related indicators, such as the share of households with fixed telephone lines, the number of computers, the number of fixed telephone lines, the share of households with a computer, today most of this data is not even published or updated. Instead, more and more attention is paid to analysis of the development of digital infrastructure, and especially the more and more advanced mobile services provided by mobile operators and Internet service providers. For example, in the latest database of the International Telecommunication Union (ITU) of 2010, among 150 indicators relating to the international telecommunications market as many as 27 are directly related to mobile services and to Internet access and usage ${ }^{4}$. This follows from the fact that the fixed telephone line or radio and television receiver ceased to symbolize civilizational advancement (especially in post-industrial Western countries), while it is the increasingly developed market for digital services (including mobile 
ones) and fast access to the global Network that have come to indicate how modern the society and the economy as a whole is ${ }^{5}$.

Table 1. Digital mobile cellular devices in 1997 and 2008

\begin{tabular}{|c|c|c|c|c|}
\hline \multirow{2}{*}{ Countries } & \multicolumn{2}{|c|}{1997} & \multicolumn{2}{|c|}{2008} \\
\hline & per 100 inhabitants & $\mathrm{EU}(27)=100$ & per 100 inhabitants & $\mathrm{EU}(27)=100$ \\
\hline Japan & 29.2 & 301 & 86.7 & 72 \\
\hline United States & 2.8 & 29 & 86.8 & 72 \\
\hline EU-27 & 9.7 & 100 & 120.3 & 100 \\
\hline Estonia & 9.0 & 93 & 188.2 & 156 \\
\hline Italy & 14.6 & 151 & 151.6 & 126 \\
\hline Lithuania & 4.3 & 44 & 151.2 & 126 \\
\hline Portugal & 14.9 & 153 & 139.6 & 116 \\
\hline Bulgaria & 0.4 & 5 & 138.3 & 115 \\
\hline Czech Republic & 4.5 & 46 & 133.5 & 111 \\
\hline Austria & 11.4 & 118 & 129.7 & 108 \\
\hline Finland & 31.0 & 320 & 128.8 & 107 \\
\hline Germany & 9.5 & 98 & 128.3 & 107 \\
\hline United Kingdom & 12.7 & 131 & 126.3 & 105 \\
\hline Denmark & 23.0 & 237 & 125.6 & 104 \\
\hline Netherlands & 9.3 & 96 & 124.8 & 104 \\
\hline Greece & 8.7 & 89 & 123.9 & 103 \\
\hline Hungary & 6.1 & 63 & 122.1 & 101 \\
\hline Cyprus & 10.4 & 108 & 117.9 & 98 \\
\hline Poland & 1.6 & 16 & 115.3 & 96 \\
\hline Romania & 0.8 & 9 & 114.5 & 95 \\
\hline Ireland & 9.4 & 97 & 113.8 & 95 \\
\hline Spain & 8.2 & 84 & 111.7 & 93 \\
\hline Belgium & 9.4 & 98 & 111.6 & 93 \\
\hline Slovakia & 3.1 & 32 & 102.2 & 85 \\
\hline Slovenia & 2.6 & 27 & 102.0 & 85 \\
\hline Latvia & 2.6 & 27 & 98.9 & 82 \\
\hline Malta & 1.3 & 13 & 94.6 & 79 \\
\hline France & 9.7 & 101 & 93.4 & 78 \\
\hline Luxembourg & 16.0 & 165 & . & . \\
\hline Sweden & 27.3 & 281 & . & . \\
\hline median (EU-27) & 9.3 & & 123.9 & \\
\hline
\end{tabular}

Source: author's calculations based on ITU World Telecommunication/ICT Indicators 2010. 
One such indicator is the number of digital mobile devices per 100 inhabitants, while the term "mobile device" shall be construed as meaning devices connected to the network on the basis of subscription plans, as well as devices with prepaid cards. Based on data presented in Table 1, it may be stated that in 1997 the value of this indicator for the European Union ${ }^{6}$ was 3 times lower than in Japan, while almost 4 times higher than in the United States. Among the European countries, only the Nordic countries (Finland, Denmark and Sweden) had indicator values similar to Japan, which is understandable considering they are the cradle of modern telecommunication services (especially Sweden and Finland). For comparison, the value for Poland, amounting to 1.6 (well below the median equal to 9.3 for the EU-27), was one of the worst in Europe - only Bulgaria, Romania and Malta had worse indicator values.

Over the decade, however, there has been a sharp increase in the number of mobile devices per 100 inhabitants of the European Union, so that the value of this index is now about $1 / 3$ higher than in Japan and the United States. Although Poland is still below the median for the whole Union, the value of this ratio is already close to the mean value. Moreover, due to the progress that has been made in the period analyzed in the Polish mobile market, as well as effective measures of the Office of Electronic Communications in ensuring competition in this market, Poland has been able even to overtake some of the countries of the "old EU", i.e. Ireland, Spain, Belgium and France.

Table 2 compares, in turn, changes in bandwidth per Internet user in 1999 and 2007, assuming that this rate reflects the pace of modernizing the telecommunications infrastructure in the countries surveyed. As one can notice, in the period studied the distance between the United States and Japan and the EU countries did not decrease significantly. In 1999, the highest bandwidth speeds were offered in Belgium, France, the Netherlands, the United Kingdom and Sweden, but in as many as 14 of the EU-27 countries the ratio was higher than in the United States (among them Malta, Latvia and Estonia), and only in six - worse than in Japan (this group included Poland).

After nearly a decade, obvious improvement can be seen in all countries studied, with record growth recorded in Luxembourg ${ }^{7}$. It is worth noting that primarily members of the "old" EU were above the median (except Spain, Greece and Portugal), which may indicate that despite the investment in telecommunication infrastructure development, increasing competition in the domestic telecommunication markets (by weakening often monopolistic position of national operators) and the EU funds, the new member states continue to lose the distance to the Western European countries (although some of them have come ahead of the United States in this respect). 
Table 2. International Internet bandwidth per Internet user in 1999 and 2007

\begin{tabular}{|c|c|c|c|c|}
\hline \multirow{2}{*}{ Countries } & \multicolumn{2}{|c|}{1999} & \multicolumn{2}{|c|}{2007} \\
\hline & $\mathrm{kbit} / \mathrm{s}$ & $\mathrm{EU}(27)=100$ & $\mathrm{kbit} / \mathrm{s}$ & $\mathrm{EU}(27)=100$ \\
\hline Japan & 0.10 & 10 & 5 & 11 \\
\hline United States & 0.27 & 28 & 15 & 33 \\
\hline EU-27 & 0.96 & 100 & 47 & 100 \\
\hline Luxembourg & 0.46 & 48 & 9,336 & 19,831 \\
\hline Netherlands & 1.75 & 183 & 91 & 193 \\
\hline Sweden & 1.20 & 125 & 61 & 129 \\
\hline United Kingdom & 1.47 & 153 & 53 & 112 \\
\hline France & 1.81 & 189 & 45 & 95 \\
\hline Denmark & 0.75 & 78 & 41 & 86 \\
\hline Belgium & 3.91 & 408 & 36 & 77 \\
\hline Germany & 0.69 & 72 & 34 & 72 \\
\hline Austria & 0.53 & 55 & 29 & 62 \\
\hline Italy & 0.27 & 28 & 25 & 54 \\
\hline Ireland & 0.58 & 61 & 25 & 54 \\
\hline Bulgaria & 0.04 & 4 & 25 & 53 \\
\hline Finland & 0.40 & 42 & 21 & 45 \\
\hline Spain & 0.22 & 23 & 20 & 43 \\
\hline Romania & 0.02 & 2 & 19 & 40 \\
\hline Estonia & 0.65 & 67 & 18 & 38 \\
\hline Czech Republic & 0.26 & 27 & 14 & 29 \\
\hline Greece & 0.06 & 6 & 13 & 27 \\
\hline Malta & 0.30 & 31 & 12 & 26 \\
\hline Slovenia & 0.15 & 16 & 12 & 25 \\
\hline Portugal & 0.06 & 6 & 11 & 24 \\
\hline Lithuania & 0.02 & 2 & 9 & 20 \\
\hline Slovakia & 0.18 & 19 & 9 & 19 \\
\hline Hungary & 0.11 & 12 & 9 & 19 \\
\hline Latvia & 0.79 & 83 & 6 & 13 \\
\hline Poland & 0.07 & 8 & 6 & 12 \\
\hline Cyprus & 0.13 & 13 & 4 & 8 \\
\hline median (EU-27) & 0.30 & & 20.4 & \\
\hline
\end{tabular}

Source: as in Table 1.

In case of Poland it is rather difficult to speak about the situation improving, because the backbone network bandwidth at $6 \mathrm{kbit} / \mathrm{s}$ per Internet user (i.e. only 12\% of EU average) puts our 
country at "the tail" of the enlarged European Union. One of the reasons for this has been the long-lasting dominant role of Telekomunikacja Polska (TP SA) as the incumbent telecom and the principal - in addition NASK - operator of the backbone network in Poland, which has not forced the company to quickly develop the network. Given the fact that the data on this indicator published by the ITU comes from the TP SA, and given the growth of the number of backbone network operators observed in the past decade (EXATEL, Railway Telecom, GTS Energis and Netia), it can be assumed that the actual value of this indicator for Poland should be higher, although it is difficult to accurately estimate it.

Another indicator informing about the state of telecommunication infrastructure is the

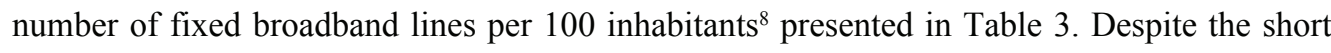
period, progress made in this respect is clearly visible in all the countries surveyed, which can somehow be regarded as confirmation of the dynamic development of the global Internet network in the past decade. In contrast to indicators presented above, at the beginning of the last decade the United States and Japan had a distinct advantage in the number of broadband connections over the European Union, and only a few EU member states could boast similar or better achievements in this area (i.e. Sweden, Belgium and Denmark).

After less than a decade, the values for Japan, the U.S. and the EU almost equalized, however, as was the case with the previously discussed indicator, again mainly countries of the "old" EU were above the median 21.6 (exceptions were Spain, Italy, Portugal, and Greece). Poland, with nearly 14 broadband connections per 100 inhabitants, again fell into one of the last places in the European Union. With decreasing disparities between member states, this is another proof of the continuing unavailability of broadband Internet access in our country.

On the other hand, in just three years (2007-2009), the availability of broadband data transfer over cellular networks has greatly improved (see Figure 1), although as yet the achieved throughput is much lower than throughput via fixed lines. However, it seems that despite increasing access to mobile broadband Internet ${ }^{9}$, the main obstacle is still a fairly high level of prices for such services and the relatively low coverage of base stations in our country that make it possible to achieve transfer rates in excess of a few megabits per second. It should also be added that further increase of the capacity of cellular networks will require significant investments (an example is the Long Term Evolution technology with which it is possible to achieve a throughput of several hundred megabits per second for mobile networks ${ }^{10}$ ). Comparing the development of this form of access to the global network in recent years (see Figure 1), it can be seen that in most countries of the European Union its popularity is significantly higher than in the United States, although the superiority of Japan in this respect is out of the question. 
Table 3. Total fixed (wired) broadband Internet subscriptions in 2001 and 2009

\begin{tabular}{|c|c|c|c|c|}
\hline \multirow{2}{*}{ Countries } & \multicolumn{2}{|c|}{2001} & \multicolumn{2}{|c|}{2009} \\
\hline & per 100 inhabitants & $\mathrm{EU}(27)=100$ & per 100 inhabitants & $\mathrm{EU}(27)=100$ \\
\hline Japan & 3.0 & 232 & 24.9 & 101 \\
\hline United States & 4.4 & 338 & 27.1 & 109 \\
\hline EU-27 & 1.3 & 100 & 24.8 & 100 \\
\hline Sweden & 6.6 & 508 & 41.1 & 166 \\
\hline Denmark & 4.4 & 342 & 37.9 & 153 \\
\hline Netherlands & 2.9 & 224 & 35.6 & 143 \\
\hline Luxembourg & 0.3 & 21 & 32.9 & 133 \\
\hline France & 1.0 & 78 & 31.1 & 125 \\
\hline Germany & 2.6 & 197 & 30.4 & 123 \\
\hline United Kingdom & 0.6 & 43 & 29.8 & 120 \\
\hline Belgium & 4.5 & 346 & 29.4 & 119 \\
\hline Finland & 2.6 & 199 & 29.4 & 119 \\
\hline Estonia & 1.3 & 97 & 25.3 & 102 \\
\hline Malta & 2.3 & 180 & 24.4 & 98 \\
\hline Slovenia & 0.3 & 21 & 23.1 & 93 \\
\hline Austria & 4.0 & 307 & 22.5 & 91 \\
\hline Ireland & 0.0 & 0 & 21.6 & 87 \\
\hline Spain & 1.1 & 81 & 21.5 & 87 \\
\hline Cyprus & 0.3 & 24 & 20.2 & 81 \\
\hline Italy & 0.7 & 52 & 19.7 & 79 \\
\hline Czech Republic & 0.1 & 5 & 19.5 & 79 \\
\hline Lithuania & 0.1 & 5 & 19.3 & 78 \\
\hline Hungary & 0.2 & 18 & 18.8 & 76 \\
\hline Portugal & 1.0 & 74 & 17.4 & 70 \\
\hline Greece & 0.0 & 0 & 17.2 & 69 \\
\hline Slovakia & 0.0 & 0 & 14.4 & 58 \\
\hline Poland & 0.0 & 2 & 13.6 & 55 \\
\hline Romania & 0.0 & 2 & 13.2 & 53 \\
\hline Bulgaria & 0.0 & 0 & 13.0 & 52 \\
\hline Latvia & 0.1 & 11 & 11.5 & 46 \\
\hline median (EU-27) & 0.6 & & 21.6 & \\
\hline
\end{tabular}

Source: as in Table 1. 
It can even be argued that in countries where it is harder to connect to the Internet via a fixed connection, mobile technologies are gaining increasing popularity (Poland is an example, but there are also Greece, Portugal, Spain and Cyprus). Given the growing phenomenon of sacrificing fixed telephony for mobile telephony, it can be assumed that in the near future the importance of mobile technology in the access to the Internet will grow (especially in less urbanized areas, where it does not pay off for operators to invest in the fixed networks) ${ }^{11}$.

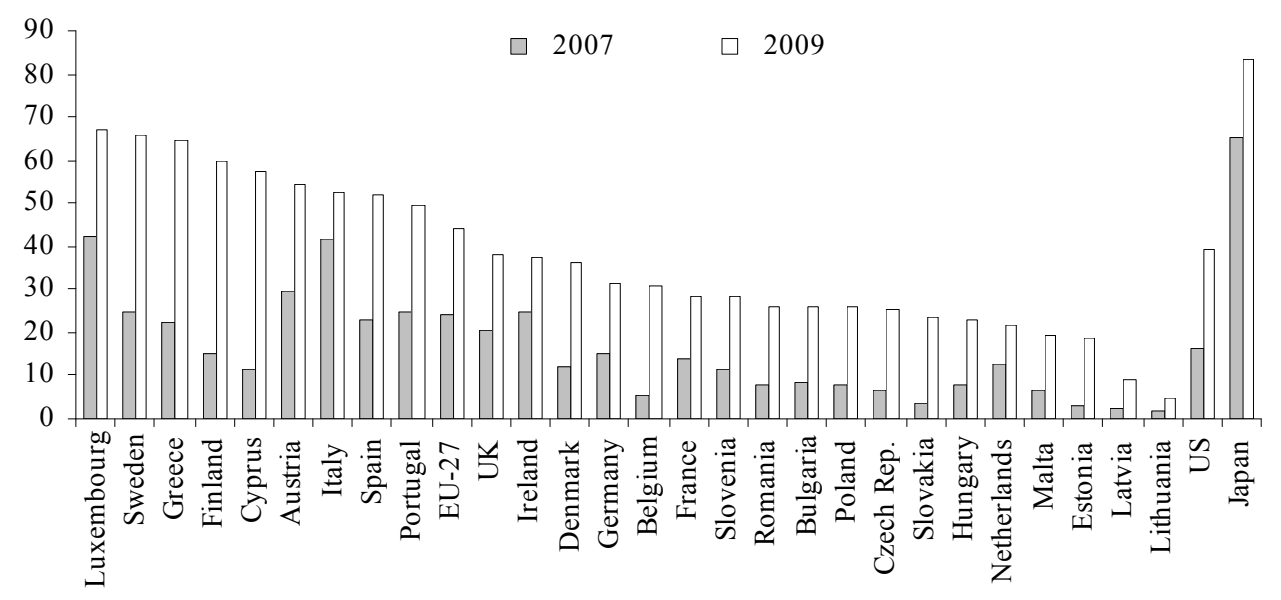

Fig. 1. Mobile cellular subscriptions with access to data communication at broadband speed per 100 inhabitants in 2007 and 2009

Source: author's calculations based on ITU (2010).

There is, therefore, no doubt that the European Union is a leader in the dissemination of high-speed internet (especially Nordic countries). However, at this point it is worth looking at the issue of popularity of the Internet understood as a modern communication medium. Figure 2 presents the number of Internet users - as a percentage of total population - in 1996 and $2009^{12}$. As can be seen, the most active Internet users in 1996 originated from Finland and the United States, while in Japan the rate was nearly two percentage points higher than the average for the EU-27. During this period Poland with an index of $1.3 \%$ occupied fourth place among the countries aspiring to EU membership (together with Slovenia, Estonia and the Czech Republic). 

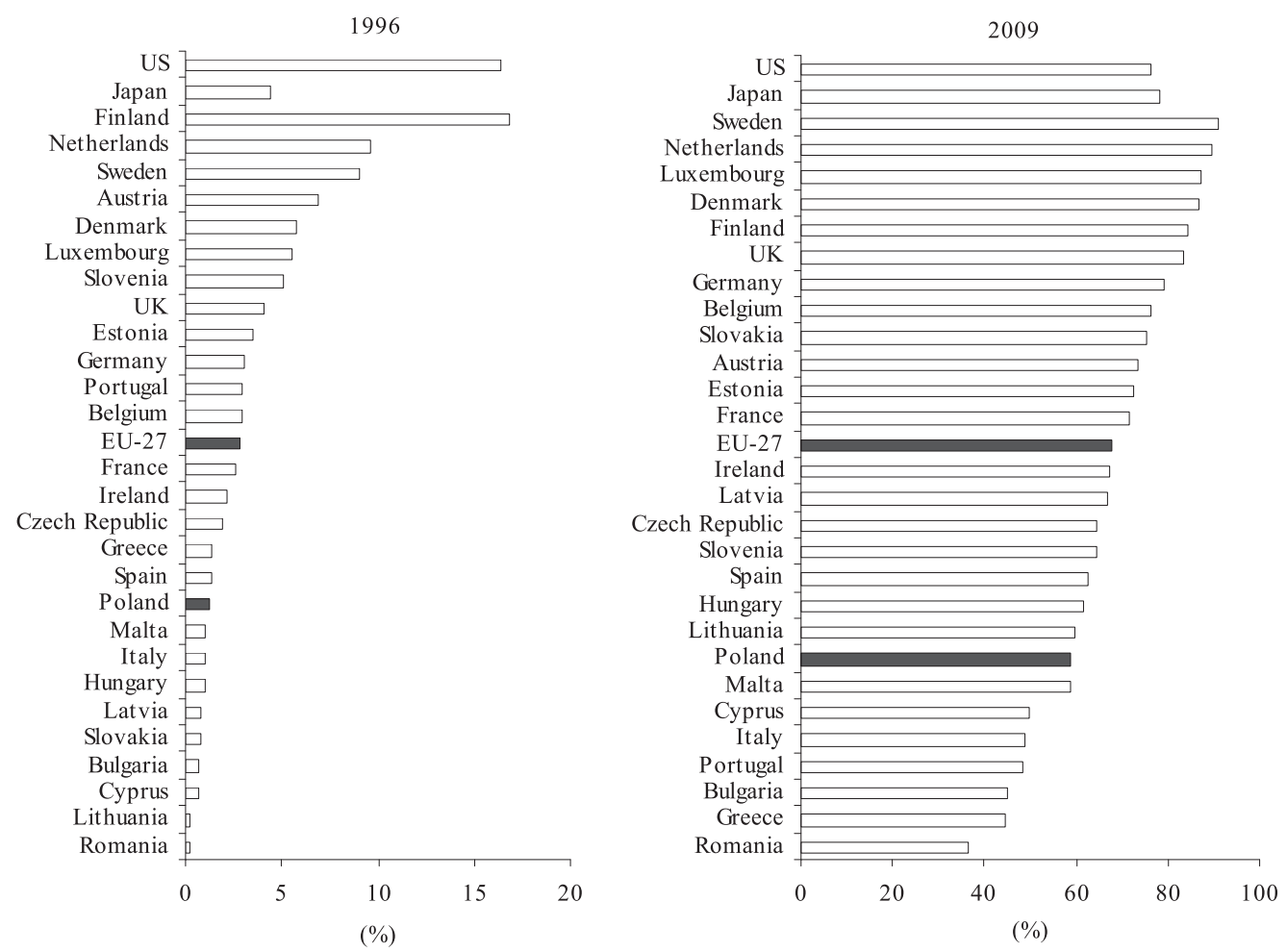

Fig. 2. Internet users as country's population percentage in 1996 and 2009 Source: as in Table 1.

The growing popularity of the Internet is confirmed by 2009 data showing that some EU countries surpassed the United States and Japan in this respect. Despite general vast improvements, as evidenced by the average percentage of Internet users in the EU at almost $70 \%$, Poland fell in this classification by two positions (this is very important since the majority of countries at the end of the classification in 1996 have improved their ranks, for example Lithuania by 7 positions, Cyprus by 3, Latvia by 8 , Hungary by 3, and Slovakia by as much as 14 positions). This means that the European Union clearly decreased disparities in terms of the number of Internet users.

Finally, it is worth analyzing changes in the synthetic Networked Readiness Index, which has been published for ten years by the World Economic Forum and which is a kind of measure of the modernity of a country's economy ${ }^{13}$. Table 4 shows the values of this index for the countries of the European Union, the United States and Japan in the two most recent editions of the ranking. Among the 133 countries covered in the study in the years 2009-2010, first place 
Table 4. Networked Readiness Index of EU-27, the United States and Japan in 2008-2010

\begin{tabular}{|c|c|c|c|c|c|}
\hline \multirow{2}{*}{ Country } & \multicolumn{2}{|c|}{ NRI 2009-2010 } & \multicolumn{2}{|c|}{ NRI 2008-2009 } & \multirow{2}{*}{ Rank change } \\
\hline & rank & score & rank & score & \\
\hline Sweden & 1 & 5.65 & 2 & 5.84 & 1 \\
\hline Denmark & 3 & 5.54 & 1 & 5.85 & -2 \\
\hline United States & 5 & 5.46 & 3 & 5.68 & -2 \\
\hline Finland & 6 & 5.44 & 6 & 5.53 & 0 \\
\hline Netherlands & 9 & 5.32 & 9 & 5.48 & 0 \\
\hline United Kingdom & 13 & 5.17 & 15 & 5.27 & 2 \\
\hline Germany & 14 & 5.16 & 20 & 5.17 & 6 \\
\hline Luxembourg & 17 & 5.02 & 21 & 5.10 & 4 \\
\hline France & 18 & 4.99 & 19 & 5.17 & 1 \\
\hline Austria & 20 & 4.94 & 16 & 5.22 & -4 \\
\hline Japan & 21 & 4.89 & 17 & 5.19 & -4 \\
\hline Belgium & 22 & 4.86 & 24 & 5.02 & 2 \\
\hline Ireland & 24 & 4.82 & 23 & 5.03 & -1 \\
\hline Estonia & 25 & 4.81 & 18 & 5.19 & -7 \\
\hline Malta & 26 & 4.75 & 26 & 4.79 & 0 \\
\hline Slovenia & 31 & 4.51 & 31 & 4.57 & 0 \\
\hline Cyprus & 32 & 4.48 & 33 & 4.52 & 1 \\
\hline Portugal & 33 & 4.41 & 30 & 4.63 & -3 \\
\hline Spain & 34 & 4.37 & 34 & 4.50 & 0 \\
\hline Czech Republic & 36 & 4.35 & 32 & 4.53 & -4 \\
\hline Lithuania & 41 & 4.12 & 35 & 4.40 & -6 \\
\hline Hungary & 46 & 3.98 & 41 & 4.28 & -5 \\
\hline Italy & 48 & 3.97 & 45 & 4.16 & -3 \\
\hline Latvia & 52 & 3.90 & 48 & 4.10 & -4 \\
\hline Slovakia & 55 & 3.86 & 43 & 4.19 & -12 \\
\hline Greece & 56 & 3.82 & 55 & 4.00 & -1 \\
\hline Romania & 59 & 3.80 & 58 & 3.97 & -1 \\
\hline Poland & 65 & 3.74 & 69 & 3.80 & 4 \\
\hline Bulgaria & 71 & 3.66 & 68 & 3.80 & -3 \\
\hline
\end{tabular}

Source: author's calculations based on Global Information Technology Report 2009-2010..., pp. 12-13.

went to Sweden, while Denmark, the United States, Finland and the Netherlands were also leading the way. The best of the new EU member states were classified at the end of the third ten (Estonia and Malta), and Poland occupied the penultimate place among all EU members states (only Bulgaria was worse). One positive change when compared to the previous ranking 
is, however, that Poland - apart from Germany and Luxembourg - has noted one of the leaps up among the presented countries, although our country's $65^{\text {th }}$ place for 133 included in the ranking does not seem to be a particularly outstanding achievement. For comparison, China has been classified in the $37^{\text {th }}$ place (NRI value of 4.31), India in the $43^{\text {rd }}$ place (NRI value of 4.09), Brazil in the $61^{\text {st }}$ place (NRI value 3.80), and Azerbaijan is directly in front of Poland ${ }^{14}$.

\section{The consequences of neglect in the process of building the information society in Poland}

The data presented has raised concerns about the future importance of Poland and its inhabitants in the world economy. In fact this issue is extremely important, especially because of the processes taking place in the modern world, i.e. continuing globalization and growing significance of services through the dissemination of information and communication technologies, the evolution of the international division of labour and the growing importance of so-called creative industries (such as new media, audio-visual arts, music, design, software, video game production ${ }^{15}$ ). Not insignificant is the changing attitude of the world economy actors (including transnational corporations) to new opportunities for the diffusion of knowledge and successful collaboration in global innovation and research and development. Especially the latter concept referred to as "open innovation"16 (which means, in short, that in the modern networked economy companies can not only rely on their own research, but on the one hand should obtain patents, licenses and other innovative solutions from other companies, and on the other share their inventions and intellectual propriety to other parties by way of licenses, formation of syndications and investing in spin-off companies) should be particularly dear to such uninnovative countries like Poland. Maintaining or even deepening of Polish backwardness in terms of access and commercial use of ICT can lead, in the long term, to permanent deterioration of the competitiveness of our country in the international arena, while in the shorter term will contribute to the occurrence of the following - in part already observed - negative effects:

1. Deepening problems in the labour market due to the shortage of graduates in science and engineering, as well as the inadequacy of educational programs for the needs of entrepreneurs and mismanagement of ICT usage in education at different levels. As is well known, telecommuting is not yet a popular form of working on the Polish market, and relatively few entities - both companies and employees - use the possibilities of distance learning (e-learning) in order to raise their professional qualifications. 
In combination with low employee mobility (as compared to Western European countries, and especially the U.S.), this translates into increasing difficulties in finding suitable staff, as well as perpetuates the previously presented disparities between regions and weakens the relationships between large agglomerations and their immediate socioeconomic environment.

2. The existence of a small social capital, widely recognized as a major factor in economic competitiveness, which includes interpersonal trust, voluntary membership in organizations, participation in non-compulsory public meetings, voluntary action for the local community, participation in parliamentary elections and a positive attitude towards democracy ${ }^{17}$. As latest international research shows, human capital is a more important premise of development than social capital in poorer countries, among which Poland can still be counted, but beyond a certain threshold of wealth social capital becomes the crucial incentive for further development. This explains the current good economic growth rate in Poland, despite the very low level of social capital, and explains in part the interest of foreign investors in our country. According to J. Czapiński, in about 10 years Poland will exceed the threshold of wealth, beyond which further investment in human capital will no longer be enough in order to sustain development ${ }^{18}$. This will coincide in time with the expiry of the privileges for foreign direct investors, which may cause their rushing outflow abroad. Information and communication technologies, because of their network nature, are an excellent medium for building social capital, some positive signs of which have already been seen (for example, various ad hoc actions organized via social networks such as Facebook). On the other hand, however, there is still a lack of support from the authorities for such processes, as exemplified by, inter alia, continuous, unsupported by concrete actions discussions about participation in elections or referendums via the Internet.

3. Possible further widening of digital exclusion of residents of less urbanized areas, especially when it comes to the growing group of older people. As mentioned, the priority task in combating this phenomenon seems to be raising awareness of opportunities offered by the development of the Internet (which therefore necessitates a radical change in education, as well as promoting the habit of constant self-education and raising qualifications). Moreover, the dissemination of such knowledge can contribute significantly to the prevention of many already observed, negative demographic and social processes, i.e. increasing proportion of economically inactive people, difficulty in finding work by people of pre-retirement age, problems with the performance of many 
everyday activities by people with disabilities and the elderly. Moreover, investments stimulating development of e-government and contributing to the development of small and medium enterprises should serve to counter digital exclusion as well ${ }^{19}$.

4. Low rate of change of habits when it comes to Internet usage, namely the dominant role of the network as a place of entertainment, communication and information search, rather than creation of useful content and dissemination of innovative ideas. Studies carried out in the already cited report "Diagnoza społeczna 2009" clearly showed that the percentage of Poles for whom the use of Internet consists not only in being a recipient, but also in the possibility of being a creator and broadcaster is so far changing relatively slowly. It is true that the number of people who have had such experience is definitely larger, but still few Internet users own and actively create their website or blog (web $\log$ ), or disseminate other works (such as graphics, photos, music or videos) ${ }^{20}$.

5. Deteriorating innovation of Polish economy, the level of which, according to Eurostat, is still among the lowest in the European Union ${ }^{21}$. On the one hand, this is due to the dramatically low expenditures on research and development, low share of high technology products in Polish exports, the aforementioned problems in the labour market and the small effects of commercialization of research results. The relatively worse broadband access than in other developed countries and the aforementioned, fairly widespread inability to use the resources of the Web commercially, will further worsen the problems with free exchange of ideas and diffusion of knowledge on the international scale that are already visible in our country.

6. Weakening of the competitive position of Poland in the creative industries and modern intellectual services, in which we are falling behind not only developed countries but increasingly also countries that are recognized as developing ones. The best examples are the leading role of China in world exports of goods originating from the creative industries $^{22}$ and the year by year growing importance of India in the international market for ICT services ${ }^{23}$. The fact that India has become a major world power in the field of nuclear energy and biomass energy, in telecommunications and biotechnology, not only reflects a deep social and economic transformations that have occurred in this country in the last decade (resulting in a surge of foreign direct investments), but also a revolution in the education market as a consequence of the dissemination of ICT. Suffice it to say that the Indian government program provides every child in school with an inexpensive personal microcomputer ${ }^{24}$, while the program of giving laptops to 
each Polish school pupil that had been announced with a bang a few years ago, turned out to be merely a political marketing ploy.

\section{Conclusions}

In summary, the following conclusions may be formulated:

- in the past two decades, the state of ICT infrastructure and availability of the Internet in Poland have improved markedly, but we still in many respects depart downward from most European Union countries, Japan and the United States;

- despite a number of projects to modernize the infrastructure in recent years also performed with the strong involvement of EU funds, can not determine that the Polish citizens are in a comparable way as the inhabitants of Western Europe to enjoy access to global networks;

- digital divide persists between large agglomerations and rural areas, and the consequences of this state of affairs may be so severe that in the near future the competitiveness of Polish economy will significantly worsen in comparison with the post-industrial countries and many countries still regarded as developing (primarily BRIC countries, namely Brazil, Russia, India and China);

- although authorities of our country are making true efforts to attract as much foreign direct investment as possible, assuming that it will create jobs and sustain technological and organizational progress, however, they are forgetting the fact that without the development of practical skills in using the Internet and building the foundations of the digital society, we are likely to be losing the race for investment ever more often (which has recently happened even in traditional industries such as the automotive industry);

- this may cause the situation in which Poland will continue to be seen as a provider of semi-skilled and cheap labour, and not a serious partner with whom it is possible to jointly pursue innovative projects in response to the growing challenges of contemporary world economy.

\section{Notes}

1 Flejterski, Wahl (2003), p. 33 and subsq.

2 For more on this topic, see e.g. Gryczka (2007), pp. 22-25. 
3 The importance of the Internet in the process of building the information society and knowledge economy was first recognized by Finland, which in mid-2010 guaranteed to its citizens the right to broadband Internet access with a speed of at least 1 megabit per second within the framework of the so-called universal services. In this way, the right to access the Internet was considered as important as the right to education or to use public health services (see Gazeta Wyborcza of 7.01.2010).

4 ITU (2010).

5 Meijers, Dachs, Welfens (2008), p. 34 and subsq.

6 In order to ensure comparability of data, the average for the European Union in the 90s of the last century has been calculated taking into account the subsequent 12 new member states. A similar approach was adopted in subsequent Tables and Figures.

7 It must be remembered that the implementation of infrastructure investments in smaller countries can proceed much faster than in larger countries such as Poland.

8 According to the methodology of the ITU, a broadband connection is one that allows data downloading with speed not less than $256 \mathrm{kbit} / \mathrm{s}$, which nowadays seems to be too slow for downloading multimedia or video streams.

9 According to the report "Diagnoza społeczna 2009" most connections in Poland have a throughput of $1 \mathrm{Mbit} / \mathrm{s}$, although there are still many connections at $512 \mathrm{kbit} / \mathrm{s}$. In the years 2007-2009, a marked increase in bandwidth could be seen, but still only a small proportion of households with Internet access have a connection with bandwidth of at least $6 \mathrm{Mbit} / \mathrm{s}$ (less than 7\% of households having fixed access lines, located mainly in large urban areas). See Batorski (2009), p. 283 and subsq.

${ }^{10}$ Dahlman, Parkvall, Skold, Beming (2007), p. 277 and subsq.

${ }^{11}$ In Poland, the impetus for the development of FTTH (Fiber-to-the-Home) services can be given by the entry into force of the regulation prepared by the Ministry of Infrastructure imposing a duty on developers to bring fiber cable to every newly built home (see "Gazeta Wyborcza" of 16.09.2010).

12 The term "Internet users" encompasses those who have used the Internet (including via mobile phones) in the past 12 months.

${ }^{13}$ This index includes three components (sub-indices): the index for the environment (market, political and infrastructural), index of willingness to use modern technology (especially ICT) and the index of actual use of those technologies (in the latter two cases data concerning individuals, companies and administrative bodies are analyzed separately). In the latest rankings for $2009-2010,57 \%$ is survey data (39 component indicators) and $43 \%$ is "hard" statistical data (29 component indicators). See Dutta, Mia (2010), pp. 5-8.

14 Ibidem, pp. 12-13.

${ }^{15}$ More on this topic, see e.g. UNCTAD (2008), Gryczka (2010).

${ }^{16}$ More on this concept, see e.g. Chesbrough (2006), Lindegaard (2010). It is worth noting that in addition to the similarity of names, the concept of "open innovation" has little in common with the popular in the IT industry "open source" model, whose members oppose the patenting and selling of innovative solutions, while they are in favor of free circulation of knowledge in order to promote innovative solutions (for example, products developed on the basis of "open source" are the Linux operating systems).

17 Czapiński (2009), p. 271.

${ }^{18}$ Ibidem, p. 279.

${ }^{19}$ Commission of the European Communities (2009), pp. 46-47.

${ }^{20}$ Batorski (2009), p. 309.

${ }^{21} \mathrm{http}$ //epp.eurostat.ec.europa.eu/portal/page/portal/science_technology_innovation/introduction (as of 10.06.2011)

${ }^{22}$ UNCTAD (2008), p. 110 and subsq.

${ }^{23}$ In 2008, India occupied the sixth place among the largest exporters of telecommunications services and was in the second place (preceded by the European Union, but ahead of the U.S.) in exports of computer services - WTO (2010), pp. 140 and 149.

${ }^{24}$ Mroziewicz (2010). 


\section{References}

Batorski, D. (2009). Korzystanie z technologii informacyjno-komunikacyjnych, in: Diagnoza społeczna 2009. Warunki i jakość życia Polaków. J. Czapiński, T. Panek (eds), Warsaw: Rada Monitoringu Społecznego.

Chesbrough, H.W. (2006). Open Innovation. The New Imperative for Creating and Profiting from Technology. New York: Mcgraw-Hill.

Commission of the European Communities (2009). Europe's Digital Competitiveness Report, Volume 2: i2010 - ICT Country Profiles. Brussels.

Czapiński, J. (2009). Kapitał społeczny, in: Diagnoza społeczna 2009. Warunki i jakość życia Polaków. J. Czapiński, T. Panek (eds), Warsaw: Rada Monitoringu Społecznego.

Dahlman, E., Parkvall, S., Skold, J., Beming, P. (2007). 3 G Evolution: HSPA and LTE for Mobile Broadband, Oxford: Elsevier.

Dutta, S., Mia, I. (2010). Global Information Technology Report 2009-2010, ICT for Sustainability. Geneva: World Economic Forum.

Fin ma prawo do Internetu. (2010). Gazeta Wyborcza, 01.07.

Flejterski, S., Wahl, P.T. (2003). Ekonomia globalna. Synteza. Warsaw: Difin.

Gryczka, M. (2010). Changing role of BRIC countries in technology-driven international division of labor. Business and Economic Horizons, Vol. 2 (02). Prague: Prague Development Center.

Gryczka, M. (2007). Ewolucja międzynarodowego podziału pracy, in Międzynarodowe stosunki gospodarcze. Wybrane zagadnienia. J. Dudziński, H. Nakonieczna-Kisiel (eds), Szczecin: West Pomeranian Business School.

ITU World Telecommunication/ICT Indicators 2010.

Lindegaard, S. (2010). The Open Innovation Revolution: Essentials, Roadblocks, and Leadership Skills. Hoboken: John Wiley \& Sons.

Meijers, H., Dachs, B., Welfens, P.J.J. (2008). Internationalisation of European ICT Activities, Dynamics of Information and Communications Technology. Berlin-Heidelberg: Springer.

Ministerstwo Infrastruktury: światłowód będzie w każdym nowym mieszkaniu. (2010). Gazeta Wyborcza, 16.09.

Mroziewicz, K. (2010). Ile kosztuje zaniechanie. Polityka, 38 (2774).

UNCTAD (2008). Creative Economy Report 2008 - the Challenge of Assessing the Creative Economy: Towards Informed Policy-making. Geneva.

World Trade Organization (2010). International Trade Statistics 2010. Geneva. 